\title{
A highly sensitive sandwich ELISA for the determination of glycomacropeptide to detect liquid whey in raw milk
}

\author{
Norma A. Chávez • Juan Jauregui • \\ Laura A. Palomares • Karla E. Macías • \\ Mariela Jiménez • Eva Salinas
}

Received: 1 July 2011 / Revised: 23 September 2011 / Accepted: 25 October 2011 /

Published online: 18 January 2012

(C) The Author(s) 2012. This article is published with open access at Springerlink.com

\begin{abstract}
Milk processing industries and distributors have problems with adulteration of liquid milk by the addition of bovine cheese whey. Recently, the detection of fraudulent manipulation of milk with whey has focused on the identification of glycomacropeptide (GMP). Current non-immunological methods to detect GMP in dairy products are expensive and time-consuming or have low sensitivity. In this study, a novel sandwich enzyme-linked immunosorbent assay (ELISA) for the detection and quantification of whey in raw milk was developed, using a polyclonal rabbit anti-GMP antibody. Calibration curves were constructed by analyzing raw milk standards containing different known concentrations of liquid cheese whey $(0.02-$ $20 \%)$. The method had a detection limit of $0.047 \%(\mathrm{v} / \mathrm{v})$ and a quantification limit of $0.14 \%(v / v)$. The antibody showed high specificity and no cross-reaction with milk components (other than $\mathrm{K}$-casein) and was successful in detecting GMP in dairy commercial products. The recovery ratio was between $95.62 \%$ and $113.88 \%$ for all matrices tested. The intra-assay and interassay coefficients of variation were $<6 \%$ and $<7 \%$, respectively. Finally, it can be stored for 3 months in the form of a ready-to-use kit, while maintaining its accuracy and reproducibility.
\end{abstract}

N. A. Chávez · J. Jauregui • K. E. Macías

Departamento de Ingeniería Bioquímica, Universidad Autónoma de Aguascalientes,

Av. Universidad \# 940, 20131 Aguascalientes, Ags, México

\section{A. Palomares}

Departamento de Medicina Molecular y Bioprocesos, Instituto de Biotecnología, Universidad Nacional Autónoma de México, Apartado Postal 510-3, 62250 Cuernavaca, Morelos, México

M. Jiménez $\cdot$ E. Salinas $(\square)$

Departamento de Microbiología, Centro de Ciencias Básicas, Universidad Autónoma de Aguascalientes, Av. Universidad \# 940, 20131 Aguascalientes, Ags, México

e-mail: emsalin@correo.uaa.mx 


\section{高灵敏夹心酶联免疫法检测乳清中酪蛋白糖巨肽}

摘要 乳品生产企业和销售商们经常会遇到在液奶及乳制品中加入干酪乳清的问题。近年来, 通过分析酪蛋白糖巨肽 (GMP) 的含量来确定乳中是否掺杂干酪乳清。非免疫法检测乳制品中 GMP既昂贵又耗时, 而且灵敏度低。目前, 开发了一种新的夹心酶联免疫 (ELISA) 法实现了原 料乳中乳清掺假问题的定性和定量检测。该方法以多克隆兔抗酪蛋白糖巨肽作为抗体, 以已 知浓度的液态干酪乳清 $(0.02-20 \%)$ 为标准品建立校正曲线。方法的检测限为 $0.047 \%(\mathrm{v} / \mathrm{v})$, 定量限为 $0.14 \%(\mathrm{v} / \mathrm{v})$ 。抗体具有专一性, 与乳中其它成分 ( $\mathrm{K}$-酪蛋白除外) 没有交叉反应, 能 够成功的用于乳制品中酪蛋白糖巨肽的检测。对实验样品检测的检测回收率在 $95.62 \%$ $113.88 \%$ 。批间和批内变异系数分别小于 $6 \%$ 和 $7 \%$ 。该抗体在三个月内, 其准确度和重复性保 持不变, 并且可以随时取用。

Keywords Glycomacropeptide $\cdot$ Polyclonal antibodies $\cdot$ Cheese whey $\cdot$ Milk $\cdot$ ELISA

关键词 酪蛋白糖巨肽・多克隆抗体・干酪乳清·乳・酶联免疫

\section{Introduction}

Milk has a high nutritional and biological value, and therefore, it is an essential food for human consumption. However, it can be adulterated in many ways affecting its quality and that of downstream dairy products, representing a major concern not only for consumers but also for dairy industry (Oancea 2009). One of the big problems of milk processing industry and/or distributors is the liquid or dehydrated milk adulteration by adding cheese whey. Cheese whey is a cheap by-product obtained during cheese production from cow milk. Despite the fact that usually, whey addition to milk does not represent a health hazard, it has nutritional, economic, and legal implications (Alcázar et al. 2000) and is the reason for financial difficulties of big and small milk processing industry and/or distributors due to the low yield of downstream dairy products such as cheese.

Fraudulent addition of cheese whey to milk can be detected by determining the presence of glycomacropeptide (GMP), also known as caseinomacropeptide (Eigel et al. 1984), a specific compound of cheese whey that should be absent in non-adulterated milk (Benítez et al. 2001). GMP is a bioactive casein-derived whey peptide, produced when milk is treated with chymosin during cheesemaking, and K-casein is hydrolyzed into two peptides. The larger peptide, para-K-casein (residues 1-105), is incorporated in curd while the smaller one, GMP (residues 106-169), becomes soluble and part of the whey; it contains all the sugars of the K-casein (Brody 2000). Different biological activities have been attributed to GMP. It has antimicrobial, immunomodulatory, and prebiotic effects (Thomä-Worringer et al. 2006), including promoting growth of bifidobacteria (Bruck et al. 2003). These functional properties of GMP make it an interesting ingredient for use in the development of novel foods with possible healthpromoting benefits (Phelan et al. 2009).

Several methods have been developed for the detection and quantification of GMP in dairy products, including colorimetry (Fukuda et al. 2004), cation-exchange chromatography (Léonil and Mollé 1991), reversed-phase high-performance liquid chromatography (HPLC) resolution (Elgar et al. 2000; Ferreira and Oliveira 2003) coupled to mass spectrometry (Mollé and Léonil 2005), polyacrylamide gel 
electrophoresis sodium dodecyl sulfate (SDS-PAGE), and cellulose acetate electrophoresis (Galindo-Amaya et al. 2006; Nakano et al. 2007) methods based on capillary zone electrophoresis (Cherkaoui et al. 1997; Recio et al. 1996, 2000; Van Riel and Olieman 1995), spectroscopy (Meisel 1995), and mass spectrometry (De Noni and Resmini 2005). These assays require a lot of work and time, besides expensive equipment and materials, and are therefore not very suitable for routine analysis.

Recently, new strategies based on immunochemical assays have been also developed to analyze GMP, such as biosensor immunoassay (Haasnoot et al. 2004, 2006), immunoblot (Chávez et al. 2008), immunochromatographic test (Oancea 2009), and inhibition enzyme-linked immunosorbent assay (ELISA) (Bitri et al. 1993; Bremer et al. 2008; Picard et al. 1994). Immunoblot and immunochromatographic tests have low sensitivity. The biosensor immunoassay is very sensitive, but requires highpriced equipment or equipment not yet commercially available. ELISA is the most frequently used immunoassay in routine test quantification because is a simple, sensitive, and reliable assay system that allows the use of small samples volumes and the rapid analysis of high sample numbers. ELISA-based methods have been developed for detection of GMP as a marker for proteolysis in raw milk (Picard et al. 1994) or bovine milk in sheep and goat products (Bitri et al. 1993). Currently, an inhibition ELISA was developed to detect bovine rennet whey solid in skim milk powder and buttermilk powders (Bremer et al. 2008). However these dairy matrices are less complex than raw milk.

The aim of this study was therefore to develop and validate a sandwich ELISA system using polyclonal antibodies toward pure bovine GMP that will afford a more sensitive analysis of raw milk for the routine detection of GMP as an indicator of adulteration with cheese whey.

\section{Materials and methods}

\subsection{Samples, chemicals, and instruments}

Raw milk was obtained from cows bred in a farm of the Agricultural Science Center of the Autonomous University of Aguascalientes (Aguascalientes, Mexico). Cheese whey was obtained from raw milk treated with $0.0001 \%$ of chymosin (Cuamix $^{\mathrm{MR}}$, CHR Hansen, Mexico DF, Mexico). Commercial products, i.e., yogurt, dietary supplement, milk-like probiotic, soya drink, and margarine were purchased in a food market of Aguascalientes (Aguascalientes, Mexico). GMP was donated by Arla Foods Amba (LACPRODAN ${ }^{\circledR}$ CGMP-10, Viby, Denmark). Bovine serum albumin (BSA) was obtained from Equitech-Bio, INC (Kerrville, Texas, USA). IgG anti-GMP biotinylated was prepared in our laboratory using ImmunoProbe ${ }^{\mathrm{TM}}$ Biotinylation Kit supplied by Sigma-Aldrich (St. Louis, MO, USA). Alkaline-phosphatase-conjugated secondary antibody was obtained from Zymed (South San Francisco, CA, USA). Horseradish peroxidase (HRP)-ExtrAvidina ${ }^{\circledR}$ conjugated, ortho-phenylene diamine (OPD), and 5-bromo-4-chloro-3-indolyl phosphate/nitro blue tetrazolium were purchased from Sigma (St. Louis, MO, USA). Flat-bottom polystyrene 96-well microplates were obtained from COSTAR ${ }^{\circledR}$ (Cambridge, MA, USA). Absorbances were read in a Model 550 ELISA plate reader from Bio-Rad (Hercules, CA, USA). Bio-Rad Miniprotean III 
System (Hercules, CA, USA) was used for electrophoresis separation of the protein samples.

\subsection{Labeling of anti-GMP antibody}

A polyclonal antiserum against GMP was raised in New Zealand white rabbits and was purified as described elsewhere (Chávez et al. 2008). Briefly, the antiserum was treated with saturated ammonium sulfate and caprylic acid solutions to discard most of serum proteins with exception of IgG molecules. Subsequently, anti-GMP antibody was affinity-purified by using a GMP coupled column, HiTrap NHS-activated HP (GE Healthcare Bio-Science Corporation, Piscataway, NJ, USA). For covalent conjugation of antibodies with biotin, the affinity-purified antibodies were dissolved in phosphate buffered saline (PBS) $\left(7.5 \mathrm{mmol} . \mathrm{L}^{-1} \mathrm{NaCl}, 0.5 \mathrm{mmol} . \mathrm{L}^{-1} \mathrm{Na}_{2} \mathrm{HPO}_{4}\right.$, 0.5 mmol.L $\mathrm{L}^{-1} \mathrm{NaH}_{2} \mathrm{PO}_{4}$; $\mathrm{pH} 7.4$ ), at a concentration of $400 \mathrm{mg} . \mathrm{L}^{-1}$ and were mixed with $1 \mathrm{~mL}$ of biotinamidohexanoic acid 3-sulfo- $N$-hydroxysuccinimide ester sodium salt, containing $30 \mu \mathrm{L}$ of dimethyl sulfoxide. The mixture was incubated with gentle stirring for $30 \mathrm{~min}$ at room temperature. Conjugated antibodies were isolated using the gel filtration column provided by the biotinylation kit. Total protein concentration was measured, and the biotinylated anti-GMP antibodies $\left(0.5 \mathrm{mg} . \mathrm{L}^{-1}\right)$ were stored at $-20^{\circ} \mathrm{C}$ until use.

\subsection{Processing of samples}

Liquid samples (raw milk, raw milk with different amounts of whey, yogurt, dietary supplement, milk-like probiotic, and soya drink) were mixed with a trichloroacetic acid (TCA) solution to a final concentration of 0.49 mol.L ${ }^{-1}$, in order to precipitate $\mathrm{K}$ casein (Benítez et al. 2001) which cross-reacts with GMP. To recover and concentrate GMP, a second TCA treatment to a final concentration of 0.86 mol. $\mathrm{L}^{-1}$ was developed to the supernatant (Galindo-Amaya et al. 2006; Olieman and van den Bedem 1983). The precipitate was dissolved in $300 \mu \mathrm{L}$ of PBS containing $0.05 \%$ Tween 20 (PBST) and 1\% BSA (PBST-BSA). Prior to introduction in the ELISA, the solution was neutralized with 10 to $20 \mu \mathrm{L}$ of 2 mol.L ${ }^{-1} \mathrm{NaOH}$ and adjusted to final volume of $500 \mu \mathrm{L}$ with distilled water. To samples analyzed by Western blot, the precipitate was dissolved in $200 \mu \mathrm{L}$ of 0.075 mol. $\mathrm{L}^{-1}$ Tris- $\mathrm{HCl} \mathrm{pH} 8$ and, after, was neutralized and adjusted to $500 \mu \mathrm{L}$ final volume as just indicated. Margarine $(2 \mathrm{~g})$ was previously dissolved in chloroform-methanol (2:1) to remove lipids. Later, GMP was solubilized by adding water, recovered with TCA treatment to a final concentration of $0.86 \mathrm{~mol} . \mathrm{L}^{-1}$, and the precipitate was dissolved and neutralized as indicated above, to be analyzed by ELISA. Raw milk was just-milked and was assessed GMP-free by Western blot using polyclonal GMP antibodies. Dietary supplement, yogurt, and margarine contained whey as a component as it was specified in the product.

\subsection{Western blotting}

Protein samples were separated by $13.5 \%$ sodium dodecyl sulfate polyacrylamide gels (Laemmli 1970). After electrophoresis, the proteins were transferred to polyvinylidene 
difluoride membranes (Millipore; Billerica, MA, USA) by electroblotting (Towbin et al. 1979). Blots were treated with Tris buffered saline (TBS) $\left(0.5 \mathrm{~mol} . \mathrm{L}^{-1} \mathrm{NaCl}\right.$, 0.02 mol. $\mathrm{L}^{-1}$ Tris- $\mathrm{HCl}$; pH 7.4) containing 3\% BSA (TBS-BSA) for $1 \mathrm{~h}$ at room temperature and incubated at $4{ }^{\circ} \mathrm{C}$ overnight with anti-GMP antibody diluted 1:1,000 in TBS-BSA. After several washes with TBS containing $0.2 \%$ Tween-20, the membranes were incubated for $2 \mathrm{~h}$ with alkaline-phosphatase-conjugated secondary antibody diluted 1:20,000 in TBS-BSA. After washing, proteins were detected using 5-bromo-4-chloro-3indolyl phosphate/nitro blue tetrazolium.

\subsection{Sandwich ELISA procedure}

Flat-bottom polystyrene 96-well microplates were coated overnight at $4{ }^{\circ} \mathrm{C}$ with $50 \mu \mathrm{L}$ per well of carbonate buffer $\left(0.1\right.$ mol.L $\mathrm{L}^{-1} \mathrm{Na}_{2} \mathrm{CO}_{3}, 35 \mathrm{mmol} . \mathrm{L}^{-1} \mathrm{NaHCO}_{3}$; $\mathrm{pH}$ 9.6) containing $1 \mathrm{mg} / \mathrm{L}$ of purified rabbit anti-GMP antibodies. All wash steps were carried out three times with PBST, and plates were sealed with plate-sealing film during incubations to minimize evaporation. The wells were blocked with $150 \mu \mathrm{L}$ per well of PBST-BSA and were incubated for $30 \mathrm{~min}$ at room temperature. After washing, $50 \mu \mathrm{L}$ per well of each sample was added in triplicate. Standards and sample extracts diluted 1:100 in PBST-BSA were incubated for $1 \mathrm{~h}$ at $37{ }^{\circ} \mathrm{C}$ under gentle shaking on each plate. After washing, bound GMP was detected by adding $50 \mu \mathrm{L}$ per well of biotinylated rabbit anti-GMP antibodies $(1.3 \mathrm{mg} / \mathrm{L})$ and incubated for $1 \mathrm{~h}$ at $37^{\circ} \mathrm{C}$ under gentle shaking. Plates were washed again and were subsequently incubated with $50 \mu \mathrm{L}$ per well of HRP-ExtrAvidina ${ }^{\circledR}$ conjugated, diluted 1:2,000 in PBST-BSA for $1 \mathrm{~h}$ at $37^{\circ} \mathrm{C}$. After a final wash, each well was incubated with $50 \mu \mathrm{L}$ of the substrate solution, a mixture (1:4) of citrate buffer $\left(0.05\right.$ mol. $\mathrm{L}^{-1}$ citric acid, 0.1 mol.L ${ }^{-1} \mathrm{Na}_{2} \mathrm{HPO}_{4}$; $\mathrm{pH}$ 5.2), and OPD solution (7 mmol.L ${ }^{-1} \mathrm{H}_{2} \mathrm{O}_{2}$, $333 \mathrm{mg} / \mathrm{L}$ OPD). Color development was stopped by the addition of $50 \mu \mathrm{L}$ per well of 2 mol.L $\mathrm{L}_{2}^{-1} \mathrm{H}_{2} \mathrm{SO}_{4}$. Absorbance was read at $490 \mathrm{~nm}$ in an ELISA plate reader.

Incubation times (of antigen, conjugated antibody, substrate solution) and ratios of immunoreagents (capture antibody, conjugated antibody, ExtraAvidina ${ }^{\circledR}$ enzyme), that provided the reaction of optical density proximal to 1.0 were determined and then used in sandwich ELISA.

\subsection{Standard curve generation}

The standard curve was constructed by analyzing liquid raw milk containing known concentrations of cheese whey- $0.0 \%, 0.02 \%, 0.08 \%, 0.25 \%, 0.5 \%, 1.0 \%, 2.5 \%$, $5.0 \%, 10.0 \%$, and $20.0 \% \mathrm{v} / \mathrm{v}$. The ELISA sandwich was carried out as described above. Each concentration was tested in triplicate on three consecutive days. The absorbance obtained was plotted versus the logarithmic percentage of whey.

2.7 Assay validation: specificity, accuracy, limit of detection, limit of quantification, and precision

The specificity and the accuracy of the method were estimated using samples obtained from raw milk, two different milk-like probiotics, and a soya drink. All were drink foods free of GMP and whey. The specificity of the method was established by cross-reactivity 
studies, processing, and analyzing triplicates of four samples of each drink food. The accuracy was evaluated using recovery experiments. Triplicates of four samples of each drink product spiked with $5 \%, 10 \%$, and $20 \%(v / v)$ of cheese whey were processed and analyzed by ELISA sandwich. The percentage of recovery and the coefficient of variation $(\mathrm{CV})$ were determined.

The limit of detection (LOD) and the limit of quantification (LOQ) were calculated through 25 measurements of the blank raw milk (without GMP and without whey). We applied the following formulas - $\mathrm{LOD}=3.3 \mathrm{SD} / \mathrm{S}, \mathrm{LQ}=10 \mathrm{SD} / \mathrm{S}$, where $\mathrm{SD}$ is the standard deviation of the response and $S$ is the slope of the calibration curve (ICH 2005).

To evaluate the precision within and between assays, three different dairy products containing whey (yogurt, margarine, and dietary supplement) were processed, and the extracted samples were stored at $-20^{\circ} \mathrm{C}$, and each analysis was developed with freshly thawed extracts. Intra-assay precision was determined as the mean of CVs based in ten replicates and interassay precision as the mean $\mathrm{CVs}$ on the basis of quadruplicate analyses on nine different days. A $\mathrm{CV}<10 \%$ was taken as an acceptance criterion of precision or reproducibility (Crowther 2000).

\section{Results and discussion}

\subsection{Removal of $\mathrm{k}$-casein and recovery of GMP from the samples}

All the samples were processed by two successive TCA precipitation procedures to avoid interfering $\mathrm{K}$-casein and recover GMP. The effectiveness of this procedure was demonstrated by Western blot analysis of processed and unprocessed milk samples, revealed with the polyclonal anti-GMP antibody (Fig. 1). The antibody detected a band of $19.2 \mathrm{kDa}$ in unprocessed raw milk, which correspond to the molecular weight of the K-casein (Rachagani and Gupta 2008). No bands appeared when raw milk was processed by TCA precipitation, indicating the total removal of the $\mathrm{K}$-casein from the sample and the absence of GMP. Besides, it showed that the antibody does not cross-react with other milk components. When raw milk containing $1 \%(v / v)$ of cheese whey was processed and analyzed by Western blot, two bands of 17.2 and $14 \mathrm{kDa}$ were

Fig. 1 Effectiveness of the procedure of sample precipitation with TCA. Lane 1, $5 \mu \mathrm{L}$ of unprocessed raw milk; lane $2,20 \mu \mathrm{L}$ of TCA processed raw milk; lane $3,20 \mu \mathrm{L}$ of TCA processed raw milk containing $1 \%(v / v)$ of cheese whey; lane 4, $20 \mu \mathrm{g}$ of pure GMP. Molecular weight markers and protein sizes $(\mathrm{kDa})$ are indicated in the left side of the gel

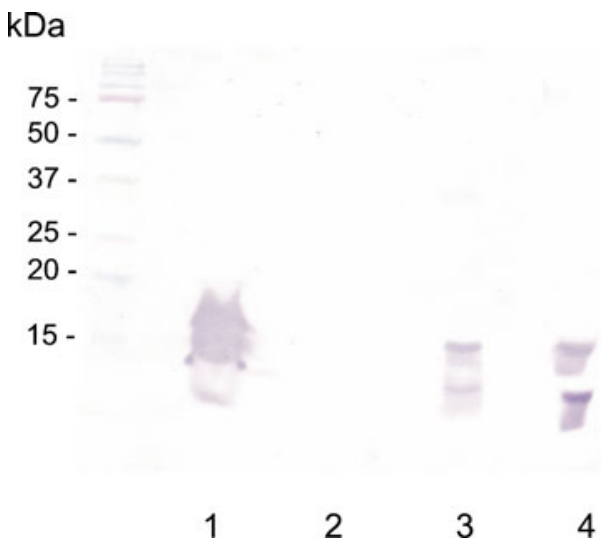


detected. These two bands correspond to that observed in pure GMP sample, showing the effectiveness of the TCA precipitation procedure in GMP recovery.

\subsection{Sandwich ELISA standard curve}

Raw milks containing cheese whey from $0.02 \%$ to $20 \%(v / v)$ were used as standards. The nine-point standard curve showing the means and standard deviations of three triplicate curves is shown in Fig. 2. When no cheese whey was added to raw milk, an absorbance value of $0.3080 \pm 0.0046$ was obtained. It was observed that absorbance values increase proportionally with the logarithm of the concentration in the standard curve range with a squared correlation coefficient $\left(R^{2}\right)>0.993$.

\subsection{Specificity}

The specificity of the antibodies was demonstrated in the ELISA system using raw milk and other two commonly used drink foods, a milk-like probiotic and a soya drink. Four samples of each drink food were analyzed in triplicates. There was no positive reaction when raw milk was analyzed $(0.0027 \pm 0.0004 \%$ of whey $v / v)$, indicating that the polyclonal anti-GMP antibody did not cross-react with other components of raw milk. Therefore, there was no possibility of false-positive as a result of cross-reactivity. This fact increased the veracity of the test for detecting adulteration of raw milk with cheese whey. When a milk-related matrix as probiotics or a rich-protein not milk-related matrix as soya drink was evaluated, no cross-reaction was obtained $(0.0017 \pm 0.0002$ and $0.0073 \pm 0.0006 \%$ of whey $v / v$, respectively), supporting the specificity of the polyclonal anti-GMP antibody.

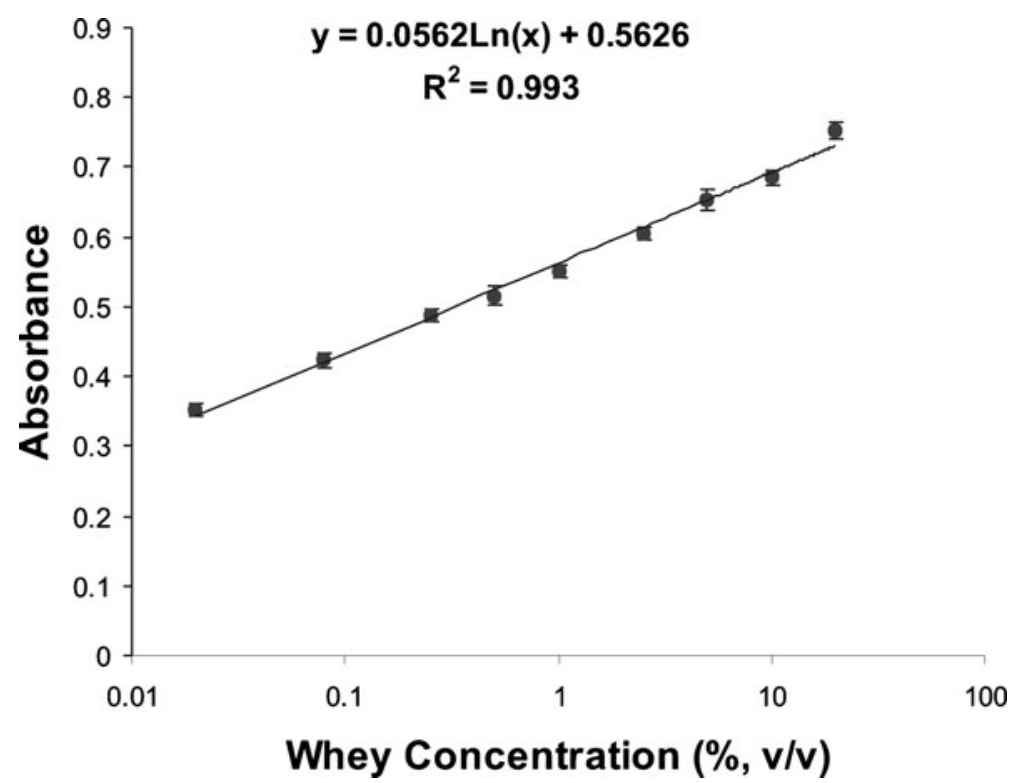

Fig. 2 Sandwich ELISA linear nine-point calibration curve. It was constructed by analyzing raw milk standards containing known concentrations of liquid cheese whey. Each point represents the average of three triplicate curves, and error bars represent standard deviations 


\subsection{Accuracy}

The accuracy of the method was studied with recovery experiments. Four kinds of drink foods were fortified with whey at three different levels $(5 \%, 10 \%$, and $20 \%)$, and the whey concentration was determined using sandwich ELISA. Each sample was tested at least four times in triplicates to verify the repeatability of the assay. The results are shown in Table 1 . The recoveries of whey in the samples were between $95.62 \pm 4.04 \%$ and $113.88 \pm 3.44 \%$, confirming the accuracy of the ELISA. The differences in the matrix sample did not affect the recovery ratios.

To demonstrate that pre-coated ELISA plates can be stored for long time in the form of ready-to-use kits, we analyzed in the same day raw milk samples spiked with $20 \%(v / v)$ of cheese whey, developing the assay in coated anti-GMP ELISA plates which were stored at $-20^{\circ} \mathrm{C}$ for 30,45 , and 60 days. Data of recovery percentage and $\mathrm{CV}$ are showed in Table 2 . The recovery ratio was satisfactory when samples were analyzed with pre-coated plates stored for 30,45 , or 60 days, with results very similar to that obtained with just-coated plates. We determined that, after storage of the coated ELISA plates for 3 months, the assay kept its accuracy and reproducibility. This suggests that sandwich ELISA can be utilized in ready-to-use kits for the routine analysis of milk.

\subsection{Limit of detection and limit of quantification}

To obtain the LOD and the LOQ for this sandwich ELISA, raw milk was analyzed as a blank. The LOD for the ELISA sandwich was $0.047 \%(v / v)$ of liquid whey in raw milk which means that $0.047 \%$ is the lowest amount of liquid cheese whey that can be detected in a sample. The LOQ of the assay was $0.14 \%(v / v)$, indicating that, from this concentration, the sandwich ELISA can discern with certainty whether a sample contains cheese whey or not and can quantify it. Using immunochemical assays as immunoblot (Chávez et al. 2008), immunochromatographic test (Oancea 2009), and biosensor immunoassay (Haasnoot et al. 2004, 2006), authors report LODs of $0.5 \%$,

Table 1 Accuracy of the sandwich ELISA assay

Percentage of whey recovered in a GMP- and whey-free drink food spiked with $5 \%, 10 \%$, and $20 \%$ of liquid whey ${ }^{\text {a }}$ Values are mean $\pm \mathrm{SD}, n=4$ in triplicate

$\begin{array}{lllll}\text { Drink food } & \begin{array}{l}\text { Spiked } \\ \text { level }^{\mathrm{a}}(\%)\end{array}\end{array} \quad$ Detected $^{\mathrm{a}}(\%) \quad$ Recovery (\%) CV (\%)

\begin{tabular}{lrrrr}
\hline Raw milk & 5 & $4.80 \pm 0.30$ & $96.12 \pm 6.01$ & 6.25 \\
& 10 & $10.33 \pm 0.64$ & $103.30 \pm 6.46$ & 6.19 \\
& 20 & $22.66 \pm 0.88$ & $113.30 \pm 4.41$ & 3.88 \\
Probiotic 1 & 5 & $4.78 \pm 0.20$ & $95.62 \pm 4.04$ & 4.18 \\
& 10 & $10.60 \pm 0.56$ & $106.05 \pm 5.66$ & 5.28 \\
& 20 & $22.77 \pm 0.68$ & $113.88 \pm 3.44$ & 2.98 \\
Probiotic 2 & 5 & $4.95 \pm 0.25$ & $99.12 \pm 5.09$ & 5.05 \\
& 10 & $10.79 \pm 0.63$ & $107.98 \pm 6.30$ & 5.83 \\
& 20 & $22.08 \pm 0.81$ & $110.41 \pm 4.08$ & 3.66 \\
Soya drink & 5 & $4.87 \pm 0.30$ & $97.42 \pm 6.08$ & 6.16 \\
& 10 & $10.72 \pm 0.97$ & $107.20 \pm 9.75$ & 9.04 \\
& 20 & $22.67 \pm 0.73$ & $113.38 \pm 3.68$ & 3.22 \\
\hline
\end{tabular}


Table 2 Effect of storage at $-20^{\circ} \mathrm{C}$ of anti-GMP pre-coated ELISA plates on the accuracy

\begin{tabular}{llll}
\hline Days & Detected $^{\mathrm{a}}(\%)$ & Recovery $^{\mathrm{a}}(\%)$ & CV (\%) \\
\hline 0 days & $22.62 \pm 0.66$ & $113.13 \pm 3.31$ & 2.91 \\
30 days & $22.78 \pm 0.74$ & $113.90 \pm 3.71$ & 3.24 \\
45 days & $21.55 \pm 0.78$ & $107.75 \pm 3.92$ & 3.61 \\
60 days & $21.26 \pm 0.80$ & $106.33 \pm 4.04$ & 3.76 \\
\hline
\end{tabular}

Percentage of whey recovered in a GMP- and whey-free raw milk to which $20 \%$ of liquid whey was added

${ }^{\text {a }}$ Values are mean $\pm \mathrm{SD}, n=8$

$1-2 \%$, and $0.17 \%$ of liquid whey in raw milk, respectively. By inhibition ELISA system, a greater sensitivity is reported using monoclonal antibodies anti-K-casein, with a detection limit of $0.1 \%(w / w)$ of whey powder in skim milk powder (Bremer et al. 2008). It is important to consider that in liquid milk, which is the one we used, solids (including whey cheese) are in lower concentration (a 12\% average) because it is a water-based sample. Our ELISA system had an equivalent LOD of $0.03 \% w / w$ of whey in skim milk powder.

The European Union (EU) has regulated the use of HPLC method for GMP determination to detect fraudulent addition of solid whey to the skimmed power milk destined for stockpiling (EC 273/2008). The proteolytic activity of psychrotrophic proteinases on milk, although less specific than chymosin, can also split K-casein at positions 105-106, which leads to the formation of GMP (Recio et al. 2000). To minimize the risk of false-positive test results, the EU has set the decision level at a relatively high concentration, i.e., $1 \%(w / w)$ of solid whey. There is no regulation related to fraudulent addition of liquid cheese whey to raw milk. Considering that liquid milk has lower concentration of solids, we can also set the decision level of our assay at the $95 \%$ confidence interval of raw milk standard containing $1 \%(v / v)$ of liquid whey. The average concentration and SD of nine analyses of the $1 \%(v / v)$ of raw milk standard were $0.994 \%$ and $0.057 \%$, respectively. The decision level calculated as average minus $2 \mathrm{SD}$ was set at $0.88 \%(v / v)$. Thus, all samples containing $0.88 \%(v / v)$ or more cheese whey according to our assay are potentially positive.

\subsection{Precision}

In order to evaluate the intra-assay and interassay variances, three products that contain whey (as a labeled ingredient): yogurt, margarine, and dietary supplement were analyzed by sandwich ELISA. The samples were analyzed in quadruplicate, and the average of measurements of three different days is shown in Table 3 . They were found to contain cheese whey in amounts ranging from $10 \%$ to $13 \%(v / v)$. The ELISA showed a high repeatability for all the samples, with $\mathrm{CV}<6 \%$ in intra-assay variance and $<7 \%$ in interassay variance.

The sandwich ELISA successfully detected GMP in commercial foods containing whey, as yogurt, margarine, and dietary supplement. As it has been demonstrated nutritional and biological properties for GMP (Brody 2000), this bioactive peptide is being incorporated in the form of ingredients into functional foods, novel foods, 
Table 3 Intra- and interassay variances $(\% \mathrm{CV})$ determined for the sandwich ELISA with whey-containing dairy products

\begin{tabular}{lccc}
\hline Dairy products & Whey concentration ${ }^{\mathrm{a}}(\%, v / v)$ & $\begin{array}{l}\text { Intra-assay } \\
\text { variance }(\% \mathrm{CV})\end{array}$ & $\begin{array}{l}\text { Interassay } \\
\text { variance }(\% \mathrm{CV})\end{array}$ \\
\hline Yogurt & $10.6 \pm 0.13$ & 5.34 & 2.01 \\
Margarine & $10.4 \pm 0.26$ & 4.15 & 3.31 \\
Dietary supplement & $13.1 \pm 0.39$ & 4.49 & 6.94 \\
\hline
\end{tabular}

${ }^{\text {a }}$ Values are mean $\pm \mathrm{SD}, n=3$ in quadruplicate

nutraceuticals, and dietary supplements with the purpose of delivering specific health benefits (Phelan et al. 2009). This ELISA system can be an excellent alternative to detect or to quantify this peptide in GMP-fortified functional foods, as well as in existing commercial preparations of purified GMP. ELISA system development was done using polyclonal anti-GMP antibody for capture and detection. The use of polyclonal rather than monoclonal antibodies is justified and acceptable for food analysis. In the case of food, the different processing techniques that are applied can denature or affect the proteins or peptides, and thereby causing destruction of specific epitopes. Using polyclonal antibodies, the probability of detection of peptides or proteins that are altered or modified as in the case of food when subjected to different processing techniques (pasteurization, warming, acidification, etc.) is higher because antibodies recognize different epitopes (Holden et al. 2005). Therefore, this ELISA system can be used to detect or to quantify this peptide in food quality checking.

3.7 Comparison of ELISA sandwich with other methods to detect whey in raw milk

As compared with colorimetric method (Fukuda et al. 2004), SDS-PAGE (GalindoAmaya et al. 2006), immunoblot (Chávez et al. 2008), and immunochromatographic tests (Oancea 2009), the sandwich ELISA assay had an appropriate specificity and the better LOD to analyze raw milks for the presence of added cheese whey. Capillary electrophoresis allows the discrimination between whey adulteration and activity of psychrotrophic proteinases, which would give ultimate specificity (Recio et al. 2000). However, the present ELISA method had easy sample preparation and short assay time. Using sandwich ELISA assay, 24 samples and eight standards for the calibration curve were analyzed in triplicate within $4 \mathrm{~h}$. Two inhibition ELISA systems have been developed to detect GMP in raw milk but report higher LODs than we obtained; one competitive ELISA is designed to study the proteolytic activity of psychrotrophic bacteria in bulk raw milk and has a LOD of $0.1 \mu \mathrm{g} / \mathrm{mL}$ of GMP in raw milk (Picard et al. 1994) and the other to detect mixtures of ovine or caprine milk in raw bovine milk, reporting the presence of $0.25 \%$ of bovine raw milk (Bitri et al. 1993).

\section{Conclusion}

This paper presents the development and validation of a sandwich ELISA system, using polyclonal anti-GMP antibodies, to detect GMP as indicative of adulteration of 
raw milk with liquid cheese whey. This method had the lowest LOD and LOQ described in a GMP ELISA assay and showed no cross-reaction with other raw milk or drink food components. The system was reproducible and had a very good accuracy. These results enable the assay to be used in quantitative or qualitative test of dairy products to quantify or detect both GMP as whey. Besides, it can be stored for a long time in the form of ready-to-use kit, pointing out as the ideal assay to be developed in routine tests of milk received by small or big milk processing industries, distributors, or even in official inspection programs.

Acknowledgments This research project was supported by grant PIBT-06-1 from the Autonomous University of Aguascalientes. Norma A. Chávez has a doctoral fellowship from CONACYT (Consejo Nacional de Ciencia y Tecnología). The authors wish to thank to Andrés Quintanar Stephano and Jose Luis Quintanar Stephano for their support given to the development of this project.

Open Access This article is distributed under the terms of the Creative Commons Attribution Noncommercial License which permits any noncommercial use, distribution, and reproduction in any medium, provided the original author(s) and source are credited.

\section{References}

Alcázar CD, Rosas J, Jaramillo CJ, Peña SD (2000) Detection of glycomacropeptide GMP as an index of dehydrated milk adulteration with rennet whey. Vet Mex 37:217-222

Benítez E, Ponce P, Noa M (2001) Detection of rennet whey in powder milk by gel filtration high performance liquid chromatography GFC-HPLC. Rev de Salud Anim 23:27-31

Bitri L, Rolland MP, Besançon P (1993) Immunological detection of bovine caseinomacropeptide in ovine and caprine dairy products. Milchwissenschaft 48:367-370

Bremer M, Kemmers-Voncken A, Boers EAM, Frankhuizen R, Haasnoot W (2008) Enzyme-linked immunosorbent assay for the detection of bovine rennet whey powder in milk powder and buttermilk powder. Int Dairy J 18:294-302

Brody E (2000) Biological activities of bovine glycomacropeptide. Br J Nutr 84:S39-S46

Bruck WM, Graverholt G, Gibson GR (2003) A two-stage continuous culture system to study the effect of supplemental $\alpha$-lactalbumin and glycomacropeptide on mixed cultures of human gut bacteria challenged with enteropathogenic Escherichia coli serotype Typhimorium. J Appl Microbiol 95:44-53

Chávez NA, Salinas E, Jauregui J, Palomares LA, Macías KE (2008) Detection of bovine milk adulterated with cheese whey by Western blot immunoassay. Food Agric Immunol 19:265-272

Cherkaoui S, Doumenc N, Tachon P, Neeser R, Veuthey J (1997) Development of a capillary zone electrophoresis method for caseinoglycomacropeptide determination. J Chromatogr A 790:195-205

Crowther JR (2000) In: Walkers JM (ed) Validation of diagnostic tests for infectious diseases, 1st edn. Humana Press, New Jersey

De Noni I, Resmini P (2005) Identification of rennet-whey solids in "traditional butter" by means of HPLC/ ESI-MS of non-glycosylated caseinomacropeptide A. Food Chem 93:65-72

EC 273/2008 Commission Regulation 273/2008/EC of 5 March 2008 Laying down community methods to be used for the analysis and evaluation of the quality of milk and milk products. O J E U L88 29.3.2008, p1

Eigel MN, Buttler JE, Ernstorm CA, Farrell HM, Harwalker VR, Jenness R, Whitney RM (1984) Nomenclature of proteins of cow's milk: fifth revision. J Dairy Sci 67:1599-1631

Elgar DF, Norris CS, Ayers JS, Pritchard M, Otter DE, Palmano K (2000) Simultaneous separation and quantitation of the major bovine whey proteins including proteose peptone and caseinomacropeptide by reversed-phase high-performance liquid chromatography on polystyrene-divinylbenzene. J Chromatogr A 878:183-196

Ferreira IM, Oliveira MP (2003) Determination of caseinomacropeptide by an RP-HPLC method and monitoring of the addition of rennet whey to powdered milk. J Liq Chromatogr Relat Technol 26:99-107

Fukuda S, Roig S, Prata LF (2004) Correlation between acidic ninhydrin and HPLC methods to evaluate fraudulent addition of whey in milk. Lait 84:501-512 
Galindo-Amaya LL, Valbuena-Colmenares E, Rojas-Villarroel E (2006) Standardization of glycomacropeptide detection with SDS-PAGE as a milk adulteration index. Rev Cient (Maracaibo) 16:308-314

Haasnoot W, Smits N, Kemmers-Voncken A, Bremer M (2004) Fast biosensor immunoassays for the detection of cows' milk in the milk of ewes and goats. J Dairy Res 71:322-329

Haasnoot W, Marchesini GR, Koopal KÑ (2006) Spreeta-based biosensor immunoassays to detect fraudulent adulteration in milk and milk powder. J AOAC Int 89:849-855

Holden L, Fæste CK, Egaas E (2005) Quantitative sandwich ELISA for determination of Lupine (Lupinus spp.) in foods. J Agric Food Chem 53:5866-5871

International Conference on Harmonization (ICH) of Technical Requirements for Registration of Pharmaceuticals for Human Use (2005) Validation of Analytical Procedures: Text and Methodology Q2 (R1)

Laemmli UK (1970) Cleavage of structural proteins during the assembly of the head of bacteriophage T4. Nature 227:680-685

Léonil J, Mollé D (1991) A method for determination of macropeptide by cation-exchange fast protein liquid chromatography and its use for following the action of chymosin in milk. J Dairy Res 58:321328

Meisel H (1995) Application of fourth derivative spectroscopy to quantification of whey protein and casein in total milk protein. Milchwissenschaft 50:247-251

Mollé D, Léonil J (2005) Quantitative determination of bovine K-casein macropeptide in dairy products by liquid chromatography/electrospray coupled to mass spectrometry (LC-ESI/MS) and liquid chromatography/electrospray coupled to tandem mass spectrometry (LC-ESI/MS/MS). Int Dairy J 15:419-428

Nakano T, Ikawa N, Ozimek L (2007) Detection of sialylated phosphorylated kappa-casein glycomacropeptide electrophoresed on polyacrylamide gels and cellulose acetate strips by the thiobarbituric acid and malachite green dye reactions. J Agric Food Chem 55:2714-2726

Oancea S (2009) Identification of glycomacropeptide as indicator of milk and dairy drinks adulteration with whey by immunochromatographic assay. Rom Biotechnol Lett 14:4146-4151

Olieman C, van den Bedem JW (1983) A sensitive HPLC method of detecting and estimating rennet whey total solids in skim milk power. Neth Milk Dairy J 37:27-36

Phelan M, Aherne A, FitxGerald RJ, O’Brien NM (2009) Casein-derived bioactive peptides: biological effects, industrial uses, safety aspects and regulatory status. Int Dairy J 19:643-654

Picard C, Plard I, Rongdaux-Gaida D, Collin J (1994) Detection of proteolysis in raw milk stored at low temperature by an inhibition ELISA. J Dairy Res 61:395-404

Rachagani S, Gupta ID (2008) Bovine kappa-casein gene polymorphism and its association with milk production traits. Genet Mol Biol 31:893-897

Recio I, López-Fandiño R, Olano A, Olieman C, Ramos M (1996) Study of the formation of caseinomacropeptides in stored ultra-high-temperature-treated milk by capillary electrophoresis. J Agric Food Chem 44:3845-3848

Recio I, García-Risco MR, Ramos M, López-Fandiño R (2000) Characterization of peptides produced by the action of psychrotrophic proteinase on K-casein. J Dairy Res 67:625-630

Thomä-Worringer C, Sørensen J, López-Fandiño R (2006) Health effects and technological features of caseinomacropeptide. Int Dairy J 16:1324-1333

Towbin H, Staehelin J, Gordon J (1979) Electrophoretic transfer of proteins from polyacrylamide gels to nitrocellulose sheets. Proc Natl Acad Sci USA 76:4350-4354

Van Riel J, Olieman C (1995) Determination of caseinomacropeptide with capillary zone electrophoresis and its application to the detection and estimation of rennet whey solids in milk and buttermilk powder. Electrophoresis 16:529-533 